\title{
Relationships Between the 2D:4D Digit Ratio, Waist Circumference, Hand Preferences, Weight, Height, Waist-to- Height Ratio and BMI in a Turkish Population
}

\author{
Relaciones entre el Promedio de Dígitos 2D: 4D, Circunferencia de Cintura, Preferencias de \\ Mano, Peso, Altura, Relación de Cintura a Altura e IMC en una Población de Turquía
}

Ozlem Ergul Erkec

ERGUL, E. O. Relationships between the 2D:4D digit ratio, waist circumference, hand preferences, weight, height, waist-to-height ratio and BMI in a Turkish population. Int. J. Morphol., 37(4):1299-1304, 2019.

SUMMARY: The 2D:4D is thought as a biomarker for prenatal androgen exposure. Some studies have reported a significant difference between the sexes. Earlier studies reported variations in different ethnic and geographic groups. 2D:4D is related to several medical conditions including cardiovascular diseases (CVD) and metabolic syndrome (MetS). The present study investigated the relationships between hand preference, ratio of the index finger (2nd digit: 2D) and ring finger (4th digit: 4D) lengths (2D:4D), height, waist-to-height ratio (WHtR), waist circumference (WC) and weight, body mass index (BMI) in a Turkish population. The study comprised 118 healthy subjects (68 males and 50 females). 2D and 4D finger lengths and some anthropometric traits (height, weight, WC) were measured. The BMI and WHtR were calculated. Hand preference was determined by using a questionnaire (Edinburgh handedness inventory). Geschwind scores were calculated to evaluate the degree of hand preference. The mean age was 26.74 (female 27.86 , male 25.89). The right hand 2D:4D was found significantly lower in males $(0.9797)$ than in females $(0.9922)(\mathrm{p}<0.001)$, but the left hand 2D:4D was insignificant. Significant correlations (negative) were observed between the 2D:4D (both left and right) and WHtR; the 2D:4D ratio (both left and right) and WC in males. However, in females, these correlations were insignificant. The R2D:4D was sexually dimorphic in a Turkish population. There were significant differences between strong right (SR) and weak left (WL) in terms of the R2D:4D. However only 5 subject's hand preference was found WL. Therefore, further studies are needed to determine the relationships between hand preference and R2D:4D in Turkish population. Further studies are needed to determine whether a larger sample population alters these possible associations between the ratio of 2D:4D and other investigated traits in a Turkish population.

KEY WORDS: 2D:4D; Body mass index; Digit ratio; Hand preference; Waist circumference.

\section{INTRODUCTION}

The ratio of the index (2nd digit: 2D) finger and ring (4th digit: 4D) finger lengths is expressed as the 2D:4D (Oyeyemi et al., 2014).2D: 4D is thought to be a marker for prenatal exposure to androgene (Jeevanandam \& Muthu, 2016). Increased exposure to testosterone results in a lower digit ratio, while decreased exposure results in higher digit ratios (Jeevanandam \& Muthu). In other words, the ratio might be negatively correlated with testosterone in the fetus (Manning \& Peters, 2009). The 2D:4D ratio is sexually dimorphic; hence, men tend to have lower 2D:4D ratio than women (Manning \& Peters). This dimorphism occurs in fetal life and is slightly influenced by puberty (Manning \& Peters). Hand preference is related to the prenatal testosterone and 2D:4D (Manning \& Peters). Sex (Manning et al., 2007;
Oyeyemi et al.) and ethnic differences have been reported in the 2D:4D ratio (Manning et al., 2003, 2004). In addition, the mean 2D:4D ratio might show important geographical variations (Manning et al., 2007).

There have been studies about the relationship between the ratio of 2D:4D and hand preference (Manning $\&$ Peters) and metabolic syndrome (MetS) markers and cardiovascular risk factors (Oyeyemi et al.; White et al., 2017). MetS is defined as a group of marks that rise the risk of a person developing diabetes mellitus or heart disease (Hoffman et al., 2015). Body mass index (BMI), waist circumference (WC), waist-to-height ratio (WHtR), are some of the anthropometric properties that are used to predict 
metabolic risk factors (Gu et al., 2018). A previous study investigated the relationship between the 2D:4D and cardiovascular risk factors and MetS indices among adults and suggested that 2D:4D is a proxy for heart relateddisease in Ilorin (Oyeyemi et al.). A relationship was reported between 2D:4D and elevated concentrations of triglycerides and 2D:4D was suggested as a tool to determine the risk for MetS (White et al.). Danborno et al. (2008) investigated the relationships between the ratio of 2D:4D and chest, hip, and waist circumferences, and BMI in Nigerians and suggested no significant relationships. Fink et al. (2003) investigated the link between the ratio of 2D:4D and BMI, WHR, and waist-to-chest ratio (WChR) and suggested that BMI was positively related to a left 2D:4D ratio in males and significant negative correlations were suggested between the right 2D:4D and left 2D:4D ratios, WchR and hip and waist circumference, in females. BMI is a popular method to determining obesity (Khullar et al., 2014). Metabolic and CVD is linked with high BMI (Chockalingam et al., 2011). Significant correlation was reported between the R2D:4D and BMI (White et al.). Low androgen levels are reported to be related with a risk of obesity in males (Fink et al., 2006). In light of this, the aim of this study was to investigate the relationships between 2D:4D ratio, hand preference, height, weight, BMI, WC, and WHtR in a Turkish population.

\section{MATERIAL AND METHOD}

Subjects: The present study comprised 118 healthy individuals comprising of 68 males and 50 females (ranging between 18 to 55 years old, mean age $=26,74$ ) all of whom were born in and live in Turkey.

Hand Preference: Edinburgh handedness inventory was used to assess the hand preference (Oldfield, 1971). Geschwind scores (GS) (Geschwind \& Behan, 1982) were calculated (Tan, 1988b) to evaluate the degree of hand preference ( Tan, 1988a; Barut et al., 2007).

2D: 4D measurement: The 2D and 4D lengths were measured with an electronic digital caliper (Alpha Tools $150 \mathrm{~mm}$, precision $0.01 \mathrm{~mm}$ ) from the proximal crease of the finger to the fingertip, when digits were completely protracted on the ventral surface of both hands (Jeevanandam \& Muthu). The digits were measured twice on both hands, and the mean was calculated (Oyeyemi $e t$ $a l$.). The ratio of $2 \mathrm{nd}$ and 4 th digit lengths was calculated by dividing the mean lengths of the $2 \mathrm{D}$ into the $4 \mathrm{D}$ (Oyeyemi et al.). The ratio was calculated for the right and left hands separately (Jeevanandam \& Muthu).
Anthropometric measurements: Weight (kg) was measured using a digital scale (Geonaute, precision 0.1 $\mathrm{kg}$ ). Subjects were weighed while in light clothes and barefoot (Oyeyemi et al.). Height $(\mathrm{cm})$ was measured using a wall mounted stature meter (Mesilife, $0.1 \mathrm{~cm}$ ) while subjects were barefoot. BMI $(\mathrm{kg} / \mathrm{m} 2)$ was calculated by dividing the weight by the square of height (Oyeyemi et al.). WC (cm) was measured from the midpoint between the iliac crest and the lower rib after exhaling while subjects were standing (Oyeyemi et al.) using a head and waist measuring scoop (Mesilife, $0.1 \mathrm{~cm}$ ). The WHtR was calculated as dividing the WC by the height (Oyeyemi et al.).

Statistical Analysis: One way ANOVA test was used to compare group means. Differences were assessed by The Duncan multiple comparison test followed by ANOVA. The Pearson correlation analysis was used for determination of linear relationships among the variables. For determination of the relationships between categorical variables, the chi-square test was carried out. Statistical significance was accepted significant at $5 \%$. The Statistical Package for the Social Sciences (SPSS, ver: 13) statistical program was used for all statistical computations. Data are presented as mean $\pm \mathrm{SD}$.

\section{RESULTS}

Of the 118 subjects, 68 were male and 50 were female. Height and weight were significantly higher in males (height: 174.95; weight: 75.87) than in females (height: 161.36; weight: 60.78) $(\mathrm{p}<0.001)$. BMI was found significantly $(\mathrm{p}<0.05)$ lower in females $(23.29)$ than in males (24.79). The WC was significantly higher in males (86.16) than in females $(76.78)(\mathrm{p}<0.001)$. The WHtR was insignificant between males and females. The right hand 2 nd digit length (R2D), right hand 4th digit length (R4D), left hand 2nd digit length (L2D), and left hand 4th digit length (L4D) were found significantly lower in females when compared to the males (Table I, p <0.001). The ratio of R2D:4D was found significantly lower in males (0.9797) than in females $(0.9922)(\mathrm{P}<0.001)$. However, the difference between the males and females was insignificant in terms of the L2D:4D ratio.

There were significant differences between the SR, A, and WL in terms of height; the mean height was 167.37 for SR, 176.34 for A, and 177.14 for WL. There were significant differences between SR and WL in terms of the R2D:4D. The mean value of the R2D:4D was 0.9895 for SR, while it was 0.9341 for WL (Table II). 
Table I. Descriptive statistics and comparison results for the sexes.

\begin{tabular}{|c|c|c|c|c|}
\hline & & $\mathrm{N}$ & Mean \pm SD & $\mathrm{p}$ \\
\hline \multirow{2}{*}{ Age } & Female & 50 & $27.86 \pm 7624.00$ & \multirow{2}{*}{0.161} \\
\hline & Male & 66 & $25.89 \pm 7275.00$ & \\
\hline \multirow{2}{*}{ Height $(\mathrm{cm})$} & Female & 49 & $161.36 \pm 6.39$ & \multirow{2}{*}{$0.001 * *$} \\
\hline & Male & 67 & $174.95 \pm 5.45$ & \\
\hline \multirow{2}{*}{ Weight $(\mathrm{kg})$} & Female & 48 & $60.78 \pm 10.84$ & \multirow{2}{*}{$0.001 * *$} \\
\hline & Male & 67 & $75.87 \pm 12.63$ & \\
\hline \multirow{2}{*}{ BMI } & Female & 48 & $23.29 \pm 3.47$ & \multirow{2}{*}{$0.035^{*}$} \\
\hline & Male & 67 & $24.79 \pm 3.86$ & \\
\hline \multirow{2}{*}{ WHtR } & Female & 48 & $0.48 \pm 0.05$ & \multirow{2}{*}{0.161} \\
\hline & Male & 66 & $0.49 \pm 0.07$ & \\
\hline \multirow{2}{*}{$\mathrm{WC}(\mathrm{cm})$} & Female & 48 & $76.78 \pm 8.97$ & \multirow{2}{*}{$0.001 * *$} \\
\hline & Male & 66 & $86.16 \pm 13.13$ & \\
\hline \multirow{2}{*}{ R2D (mm) } & Female & 50 & $69.02 \pm 4.02$ & \multirow{2}{*}{$0.001 * *$} \\
\hline & Male & 67 & $74.59 \pm 3.73$ & \\
\hline \multirow{2}{*}{$\mathrm{R} 4 \mathrm{D}(\mathrm{mm})$} & Female & 50 & $69.62 \pm 3.98$ & \multirow{2}{*}{$0.001 * *$} \\
\hline & Male & 67 & $76.22 \pm 4.35$ & \\
\hline \multirow{2}{*}{ R2D:4D } & Female & 50 & $0.9922 \pm 0.05$ & \multirow{2}{*}{$0.001 * *$} \\
\hline & Male & 67 & $0.9797 \pm 0.04$ & \\
\hline \multirow{2}{*}{$\mathrm{L} 2 \mathrm{D}(\mathrm{mm})$} & Female & 50 & $68.07 \pm 4.00$ & \multirow{3}{*}{$0.001 * *$} \\
\hline & Male & 67 & $74.31 \pm 3.85$ & \\
\hline \multirow{2}{*}{$\mathrm{L} 4 \mathrm{D}(\mathrm{mm})$} & Female & 50 & $68.90 \pm 4.33$ & \\
\hline & Male & 67 & $76.14 \pm 4.30$ & \multirow[t]{2}{*}{$0.001 * *$} \\
\hline \multirow{2}{*}{ L2D:4D } & Female & 50 & $0.9892 \pm 0.05$ & \\
\hline & Male & 67 & $0.9768 \pm 0.04$ & 0.106 \\
\hline
\end{tabular}

Data are presented as the mean \pm SD $(* \mathrm{p}<0.05, * * \mathrm{p}<0.001)$.

The relationships between age and other traits were insignificant in females (Table III). In females, there were significant $(\mathrm{p}<0.01)$ positive relationships $($ Table III) between height and weight, height and WC, height and R4D, height and L4D, weight and BMI, weight and WHtR, weight and WC, BMI and WHtR, BMI and WC, WHtR and WC. There was also a significant relationship between height and L2D $(\mathrm{p}<0.05)$ in females.

In males, there were significant $(\mathrm{p}<0.05)$ positive correlations (Table III) between age and weight, and height and weight. There were also significant $(\mathrm{p}<0.01)$ positive correlations (Table III) between age and BMI, age and WHtR, age and $\mathrm{WC}$, height and R2D, height and R4D, height and L2D, height and L4D, weight and BMI, weight and WHtR, weight and WC, BMI and WHtR, BMI and WC, and WHtR and WC. There were significant $(\mathrm{p}<0.01)$ negative correlations (Table III) between WHtR and R2D:4D, WC and R2D:4D, and $\mathrm{WC}$ and L2D:4D. There was also a significant $(\mathrm{p}<0.05)$ negative correlation between WHtR and L2D:4D.

\section{DISCUSSION}

We investigated the relationships between R2D:4D and BMI, hand preference, height, WC, weight, and WHtR
Table II. Descriptive statistics and comparison results for the degree of hand preference.

\begin{tabular}{|c|c|c|c|c|}
\hline & & $\mathrm{N}$ & Mean \pm SD & $\mathrm{p}$ \\
\hline \multirow[t]{4}{*}{ Age } & SR & 54.00 & $29.17 \pm 8.05$ & 0.114 \\
\hline & WR & 51.00 & $23.78 \pm 4.64$ & \\
\hline & A & 5.00 & $27.00 \pm 7.52$ & \\
\hline & WL & 5.00 & $24.80 \pm 4.55$ & \\
\hline \multirow[t]{4}{*}{ Height (cm } & SR & 55.00 & $167.37 \pm 9.15^{\mathrm{b}}$ & $0.02 *$ \\
\hline & WR & 50.00 & $169.82 \pm 8.67^{\mathrm{ab}}$ & \\
\hline & A & 5.00 & $176.34 \pm 4.51^{\mathrm{a}}$ & \\
\hline & WL & 5.00 & $177.14 \pm 4.28^{\mathrm{a}}$ & \\
\hline \multirow[t]{4}{*}{ Weight $(\mathrm{kg})$} & SR & 54.00 & $67.83 \pm 13.80$ & 0.21 \\
\hline & WR & 50.00 & $69.61 \pm 14.66$ & \\
\hline & A & 5.00 & $79.40 \pm 9.64$ & \\
\hline & WL & 5.00 & $76.64 \pm 10.64$ & \\
\hline \multirow[t]{4}{*}{ BMI } & SR & 54.00 & $24.04 \pm 3.64$ & 0.86 \\
\hline & WR & 50.00 & $24.04 \pm 4.05$ & \\
\hline & A & 5.00 & $25.52 \pm 2.72$ & \\
\hline & WL & 5.00 & $24.43 \pm 3.33$ & \\
\hline \multirow[t]{4}{*}{ WHtR } & SR & 54.00 & $0.49 \pm 0.05$ & 0.87 \\
\hline & WR & 49.00 & $0.48 \pm 0.08$ & \\
\hline & A & 5.00 & $0.50 \pm 0.04$ & \\
\hline & WL & 5.00 & $0.49 \pm 0.05$ & \\
\hline \multirow[t]{4}{*}{$\mathrm{WC}(\mathrm{cm})$} & SR & 54.00 & $81.57 \pm 10.89$ & 0.51 \\
\hline & WR & 49.00 & $81.34 \pm 14.30$ & \\
\hline & A & 5.00 & $88.10 \pm 6.81$ & \\
\hline & WL & 5.00 & $87.14 \pm 7.95$ & \\
\hline \multirow[t]{4}{*}{ R2D (mm) } & SR & 55.00 & $71.64 \pm 5.29$ & 0.57 \\
\hline & WR & 51.00 & $72.66 \pm 4.44$ & \\
\hline & A & 5.00 & $74.03 \pm 2.13$ & \\
\hline & WL & 5.00 & $72.78 \pm 2.22$ & \\
\hline \multirow[t]{4}{*}{$\mathrm{R} 4 \mathrm{D}(\mathrm{mm})$} & SR & 55.00 & $72.49 \pm 5.66$ & 0.10 \\
\hline & WR & 51.00 & $73.80 \pm 4.97$ & \\
\hline & A & 5.00 & $75.10 \pm 3.35$ & \\
\hline & WL & 5.00 & $78.04 \pm 4.41$ & \\
\hline \multirow[t]{4}{*}{ R2D:4D } & $\mathrm{SR}$ & 55.00 & $0.9895 \pm 0.05 b$ & $0.04 *$ \\
\hline & WR & 51.00 & $0.9856 \pm 0.04 \mathrm{ab}$ & \\
\hline & A & 5.00 & $0.9867 \pm 0.03 \mathrm{ab}$ & \\
\hline & WL & 5.00 & $0.9341 \pm 0.04 \mathrm{a}$ & \\
\hline \multirow[t]{4}{*}{$\mathrm{L} 2 \mathrm{D}(\mathrm{mm})$} & SR & 55.00 & $70.80 \pm 5.45$ & 0.16 \\
\hline & WR & 51.00 & $71.99 \pm 4.65$ & \\
\hline & A & 5.00 & $74.56 \pm 2.90$ & \\
\hline & WL & 5.00 & $74.51 \pm 2.75$ & \\
\hline \multirow[t]{4}{*}{$\mathrm{L} 4 \mathrm{D}(\mathrm{mm})$} & SR & 55.00 & $71.97 \pm 5.93$ & 0.25 \\
\hline & WR & 51.00 & $73.68 \pm 5.29$ & \\
\hline & A & 5.00 & $74.64 \pm 2.14$ & \\
\hline & WL & 5.00 & $75.64 \pm 6.16$ & \\
\hline \multirow[t]{4}{*}{ L2D:4D } & $\mathrm{SR}$ & 55.00 & $0.99 \pm 0.05$ & 0.60 \\
\hline & WR & 51.00 & $0.98 \pm 0.03$ & \\
\hline & A & 5.00 & $1.00 \pm 0.03$ & \\
\hline & WL & 5.00 & $0.99 \pm 0.06$ & \\
\hline
\end{tabular}

Data are presented as mean $\pm \mathrm{SD}(* \mathrm{p}<0.05, * * \mathrm{p}<0.001)$.

in a Turkish population. There were significant differences between females and males in terms of height, weight, BMI, 
ERGUL, E. O. Relationships between the 2D:4D digit ratio, waist circumference, hand preferences, weight, height, waist-to-height ratio and BMI in a Turkish population.

Table III. Correlations for females and males.

\begin{tabular}{|c|c|c|c|c|c|c|c|c|c|c|c|c|}
\hline & Age & Height & Weight & BMI & WHtR & $\mathrm{WC}(\mathrm{cm})$ & R2D & $\mathrm{R} 4 \mathrm{D}(\mathrm{mm})$ & R2D:4D & $\mathrm{L} 2 \mathrm{D}(\mathrm{mm})$ & $\mathrm{L} 4 \mathrm{D}(\mathrm{mm})$ & L2D:4D \\
\hline Age & 1 & & & & & & & & & & & \\
\hline Height $(\mathrm{cm})$ & 0.011 & 1 & & & & & & & & & & \\
\hline Female & -0.169 & & & & & & & & & & & \\
\hline \multicolumn{13}{|l|}{ Male } \\
\hline Weight (kg) & & & 1 & & & & & & & & & \\
\hline Female & 0.134 & $0.537^{* *}$ & & & & & & & & & & \\
\hline Male & 0.298 & $0.289^{*}$ & & & & & & & & & & \\
\hline BMI & & & & 1 & & & & & & & & \\
\hline Female & 0.169 & 0.104 & $0.893^{* *}$ & & & & & & & & & \\
\hline Male & 0.390 & -0.102 & $0.921^{* *}$ & & & & & & & & & \\
\hline WHtR & & & & & 1 & & & & & & & \\
\hline Female & 0.220 & 0.090 & $0.712^{* *}$ & $0.814^{* * *}$ & & & & & & & & \\
\hline Male & 0.465 & -0.069 & $0.599^{* *}$ & $0.651^{\text {*** }}$ & & & & & & & & \\
\hline $\mathrm{WC}(\mathrm{cm})$ & & & & & & 1 & & & & & & \\
\hline Female & 0.239 & $0.419^{* * *}$ & $0.843^{* *}$ & $0.797^{* * *}$ & $0.942^{* *}$ & & & & & & & \\
\hline Male & 0.421 & 0.145 & $0.667^{* *}$ & $0.634^{* * *}$ & $0.977^{* *}$ & & & & & & & \\
\hline R2D (mm) & & & & & & & 1 & & & & & \\
\hline Female & 0.076 & $0.296^{*}$ & 0.004 & -0.127 & -0.092 & 0.019 & & & & & & \\
\hline Male & - & $0.471^{* *}$ & 0.121 & -0.066 & -0.175 & -0.070 & & & & & & \\
\hline $\mathrm{R} 4 \mathrm{D}(\mathrm{mm})$ & & & & & & & & 1 & & & & \\
\hline Female & 0.257 & $0.381^{* * *}$ & 0.207 & 0.056 & 0.059 & 0.191 & $0.691^{* *}$ & & & & & \\
\hline Male & - & $0.461^{* *}$ & 0.098 & -0.084 & 0.065 & 0.163 & $0.760^{* *}$ & & & & & \\
\hline R2D:4D & & & & & & & & & 1 & & & \\
\hline Female & - & -0.078 & -0.251 & -0.238 & -0.199 & -0.215 & $0.421^{* *}$ & $-0.364 * *$ & & & & \\
\hline Male & - & -0.067 & 0.017 & 0.042 & $-0.364^{* *}$ & $-0.370^{* * *}$ & 0.174 & $-0.507^{* *}$ & & & & \\
\hline $\mathrm{L} 2 \mathrm{D}(\mathrm{mm})$ & & & & & & & & & & 1 & & \\
\hline Female & 0.116 & $0.359^{*}$ & 0.065 & -0.093 & -0.104 & 0.030 & $0.918^{* *}$ & $0.719^{* * *}$ & $0.281^{*}$ & & & \\
\hline Male & - & $0.457^{* *}$ & 0.096 & -0.077 & -0.182 & -0.086 & $0.859^{* *}$ & $0.709^{* * *}$ & 0.064 & & & \\
\hline $\mathrm{L} 4 \mathrm{D}(\mathrm{mm})$ & & & & & & & & & & & 1 & \\
\hline Female & 0.156 & $0.420^{* * *}$ & 0.158 & -0.016 & 0.046 & 0.193 & $0.767^{* *}$ & $0.804^{* * *}$ & -0.005 & $0.732^{* *}$ & & \\
\hline Male & 0.019 & $0.426^{* *}$ & 0.167 & 0.011 & 0.010 & 0.097 & $0.793^{* *}$ & $0.823^{* *}$ & -0.186 & $0.762^{* *}$ & & \\
\hline L2D:4D & & & & & & & & & & & & 1 \\
\hline Female & - & -0.119 & -0.136 & -0.100 & -0.198 & -0.228 & 0.128 & -0.177 & $0.367^{* * *}$ & $0.282^{*}$ & $-0.445^{* *}$ & \\
\hline Male & - & 0.000 & -0.119 & -0.127 & $-0.269^{*}$ & $-0.265^{*}$ & -0.016 & $-0.252^{*}$ & $0.348^{* *}$ & 0.230 & $-0.454^{* *}$ & \\
\hline
\end{tabular}

WC, R2D, R4D, L2D, L4D, and the R2D:4D, but not the L2D:4D. Finger length ratio (2D:4D) has been reported as a sexually dimorphic trait (Bailey \& Hurd, 2005). Bailey \& Hurd reported stronger sexual dimorphism in the R2D:4D than in the L2D:4D. In a previous studies, the 2D:4D ratios of both hands were reported as significantly different between males and females (Beaton et al., 2011). In the present study, the ratio of R2D:4D was found significantly different between the sexes. However, the L2D:4D was found insignificant. Previous studies (Bailey \& Hurd; Flegr et al., 2005 ) reported that the ratio of $\mathrm{R} 2 \mathrm{D}$ : $4 \mathrm{D}$ was found significantly higher in females than in males and also reported stronger sexual dimorphism in the right digit ratio compared to the left (Bailey \& Hurd. It was suggested that right 2D:4D is better predictor than the left of prenatal androgenisation (Hönekopp \& Watson, 2010), in another words the relationship between testosterone and R2D:4D is suggested to be more stronger (Manning et al., 1998). Similarly, our results might be suggest that androgenization affects the R2D:4D more than the L2D:4D in the Turkish population as well.

The R2D:4D was suggested as a better predictor of cardiovascular disease (CVD) and metabolic syndrome (Oyeyemi et al.). Oyeyemi et al. reported an important association between the ratio of 2D:4D and some CVD and MetS risk factors (WC and WHtR). In the present study, no significant correlations were found between the 
2D:4D (both R2D:4D and LR2D:4D) and height, weight, BMI, WHtR, and WC in females. However, there were significant correlations (negative) between 2D:4D (both R2D:4D and LR2D:4D) and WHtR and WC in males.

It was suggested that $\mathrm{WC}$ and height have positive correlations in the average population (Mehta, 2015). Significant (positive) correlations were found between WC and height in females.

Oyeyemi et al. also reported significant correlations between some MetS markers (BMI, WC, and WHtR) and R2, R4, L2 and L4 in males and females. Correlations between digit lengths (R2,R4,L2, and L4) and BMI, WHtR, WC were insignificant in the present study.

In a previous study, it was reported that neither the ratio of R2D:4D nor L2D:4D was related to handedness (Beaton et al.). In the present study, the difference between SR, WR, A, and WL in terms of the L2D:4D was insignificant. However, we found a significant difference between SR and WL in terms of the R2D:4D. However, in the present study only 5 subject's hand preference was found WL. 2D:4D has been linked with hand preference and was reported to be associated with hand preference for writing (Manning \& Peters).

\section{CONCLUSIONS}

In conclusion, the R2D:4D was found significantly higher in females than in males. However, the difference between the sexes was insignificant in terms of the L2D:4D in the Turkish population. The R2D, R4D, L2D and L4D were significantly lower in females than in males. There were significant correlations between the digit lengths (R2, R4, L2, and L4) and height in both males and females. Significant negative correlations were found between the R2D:4D and WHtR and WC in males. Significant negative correlations were found between the R2D:4D and WHtR and WC in males. There were significant differences between SR and WL in terms of the R2D:4D. However only 5 subject's hand preference was found WL. Therefore, further studies are needed to determine the relationships between hand preference and R2D:4D.

\section{ACKNOWLEDGEMENTS}

The authors want to thank Prof. Dr. Siddık Keskin for the statistical analysis.
ERGUL, E. O. Relaciones entre el promedio de dígitos 2D:4D, circunferencia de cintura, preferencias de mano, peso, altura, relación de cintura a altura e IMC en una población de Turquía. Int. J. Morphol., 37(4):1299-1304, 2019.

RESUMEN: El 2D:4D está pensado como un biomarcador para la exposición prenatal de andrógenos. Algunos estudios han reportado una diferencia significativa entre sexos. Estudios anteriores informaron variaciones en diferentes grupos étnicos y geográficos. 2D:4D está relacionado con varias afecciones médicas que incluyen enfermedades cardiovasculares (ECV) y síndrome metabólico (MetS). El presente estudio investigó las relaciones entre la preferencia de la mano, la proporción del dedo índice ( $2^{\circ}$ dígito: $\left.2 \mathrm{D}\right)$ y el dedo anular ( $4^{\circ}$ dígito: 4D), longitudes (2D:4D), altura, relación cintura-altura (WHtR), circunferencia de cintura y peso (WC), e índice de masa corporal (IMC), en una población de Turquía. El estudio incluyó 118 sujetos sanos (68 hombres y 50 mujeres). Se midieron longitudes de dedos 2D y 4D y algunos rasgos antropométricos (altura, peso, WC). Se calcularon el IMC y el WHtR. La preferencia de la mano se determinó mediante el uso de una escala (Edinburgh Handedness Inventory). Las puntuaciones de Geschwind se calcularon para evaluar el grado de preferencia de la mano. La edad media fue de 26,74 años (femenino 27,86; masculino 25,89). La mano derecha 2D: 4D se encontró significativamente más baja en los hombres $(0,9797)$ que en las mujeres $(0,9922)(\mathrm{p}<0,001)$, pero la mano izquierda 2D: 4D fue no significante. Se observaron correlaciones significativas (negativas) entre la 2D: 4D (izquierda y derecha) y WHtR y la relación 2D: 4D (izquierda y derecha) y WC en hombres. Sin embargo, en las mujeres, estas correlaciones fueron no significantes. El R2D: 4D fue sexualmente dimorfo en una población de Turquía. Hubo diferencias significativas entre la mano derecha fuerte (SR) y la mano izquierda débil (WL) en términos de R2D: 4D. Sin embargo, sólo se encontraron 5 preferencias de mano en el sujeto con WL. Por lo tanto, se necesitan más estudios para determinar las relaciones entre la preferencia de mano y R2D: 4D en la población de Turquía. Se necesitan más estudios para determinar si una muestra mayor altera estas posibles asociaciones entre la proporción de 2D: 4D y otros rasgos investigados en una población de Turquía.

PALABRAS CLAVE: 2D: 4D; Índice de masa corporal; Relación de dígitos preferencia de la mano; Circunferencia de la cintura.

\section{REFERENCES}

Bailey, A. A. \& Hurd, P. L. Finger length ratio (2D:4D) correlates with physical aggression in men but not in women. Biol. Psychol., 68(3):21522, 2005.

Barut, C.; Ozer, C. M.; Sevinc, O.; Gumus, M. \& Yunten, Z. Relationships between hand and foot preferences. Int. J. Neurosci., 117(2):177-85, 2007.

Beaton, A. A.; Rudling, N.; Kissling, C.; Taurines, R. \& Thome, J. Digit ratio (2D:4D), salivary testosterone, and handedness. Laterality, 16(2):136-55, 2011.

Chockalingam, R.; Raghavan, R.; Agrawal, J.; Lama, G.; Lai, H. Y. A. \& Yadama, G. Understanding geographic variations in BMI in India. In: Center for Social Development. CSD Working Papers No 11-13. St. Louis (MO), Center for Social Development, Washington University, 2011. 
Danborno, B.; Adebisi, S.; Adelaiye, A. \& Ojo, S. Sexual dimorphism and relationship betweem chest, hip and waist circumference with 2D, 4D and 2D: 4D in Nigerians. Internet J. Biol. Anthropol., 1(2):1-5, 2008.

Fink, B.; Manning, J. T.; Neave, N. The 2nd-4th digit ratio (2D:4D) and neck circumference. Implications for risk factors in coronary heart disease. Int. J. Obesity, 30(4):711-4, 2006.

Fink, B.; Neave, N. \& Manning, J. T. Second to fourth digit ratio, body mass index, waist-to-hip ratio, and waist-to-chest ratio: their relationships in heterosexual men and women. Ann. Hum. Biol., 30(6):728-38, 2003

Flegr, J.; Hrusková, M.; Hodnł, Z.; Novotná, M. \& Hanusová, J. Body height, body mass index, waist-hip ratio, fluctuating asymmetry and second to fourth digit ratio in subjects with latent toxoplasmosis. Parasitology, 130(Pt. 6):621-8, 2005.

Geschwind, N. \& Behan, P. Left-handedness: association with immune disease, migraine, and developmental learning disorder. Proc. Natl. Acad. Sci. U. S. A., 79(16):5097-100, 1982.

Gu, Z.; Li, D.; He, H.; Wang, J.; Hu, X.; Zhang, P.; Hong, Y.; Liu, B.; Zhang, L. \& Ji, G. Body mass index, waist circumference, and waistto-height ratio for prediction of multiple metabolic risk factors in Chinese elderly population. Sci. Rep., 8(1):385, 2018.

Hoffman, E. L.; VonWald, T. \& Hansen, K. The metabolic syndrome. S. D. Med., Spec. No.:24-8, 2015.

Hönekopp, J. \& Watson, S. Meta-analysis of digit ratio 2D:4D shows greater sex difference in the right hand. Am. J. Hum. Biol., 22(5):619-30, 2010.

Jeevanandam, S. \& Muthu, P. K. 2D:4D Ratio and its Implications in Medicine. J. Clin. Diagn. Res., 10(12):CM01-CM03, 2016.

Khullar, K.; Agarwal, A. \& Du Plessis, S. S. BMI and Obesity. In: Du Plessis S.; Agarwal A. \& Sabanegh Jr., E. (Eds.). Male Infertility. New York, Springer, 2014. pp.31-45.

Manning, J. T. \& Peters, M. Digit ratio (2D:4D) and hand preference for writing in the BBC Internet Study. Laterality, 14(5):528-40, 2009.

Manning, J. T.; Churchill, A. J. \& Peters, M. The effects of sex, ethnicity, and sexual orientation on self-measured digit ratio (2D:4D). Arch. Sex. Behav., 36(2):223-33, 2007

Manning, J. T.; Henzi, P.; Venkatramana, P.; Martin, S. \& Singh, D. Second to fourth digit ratio: ethnic differences and family size in English, Indian and South African populations. Ann. Hum. Biol., 30(5):579-88, 2003.

Manning, J. T.; Scutt, D.; Wilson, J. \& Lewis-Jones, D. I. The ratio of 2nd to 4th digit length: a predictor of sperm numbers and concentrations of testosterone, luteinizing hormone and oestrogen. Hum. Reprod., 13(11):3000-4, 1998.

Manning, J. T.; Stewart, A.; Bundred, P. E. \& Trivers, R. L. Sex and ethnic differences in 2 nd to 4 th digit ratio of children. Early Hum. Dev., 80(2):161-8, 2004.

Mehta, S. K. Waist circumference to height ratio in children and adolescents. Clin. Pediatr. (Phila.), 54(7):652-8, 2015.

Oldfield, R. C. The assessment and analysis of handedness: the Edinburgh inventory. Neuropsychologia, 9(1):97-113, 1971.

Oyeyemi, B. F.; Iyiola, O. A.; Oyeyemi, A. W.; Oricha, K. A.; Anifowoshe, A. T. \& Alamukii, N. A. Sexual dimorphism in ratio of second and fourth digits and its relationship with metabolic syndrome indices and cardiovascular risk factors. J. Res. Med. Sci., 19(3):234-9, 2014.

Tan, U. The distribution of hand preference in normal men and women. Int. J. Neurosci., 41(1-2):35-55, 1988a.

Tan, U. The distribution of the Geschwind scores to familial left-handedness. Int. J. Neurosci., 42(1-2):85-105, 1988b.

White, M.; Jarrett, T. \& Komar, C. Correlation between digit length ratios and risk factors associated with metabolic syndrome. J. Metab. Synd., 6(1):1-5, 2017.
Corresponding author:

Ozlem Ergul Erkec

Van Yuzuncu Yil University

Faculty of Medicine

Department of Physiology

Van

TURKEY

Email:oerkec@gmail.com

Received: 12-12-2018

Accepted: 03-06-2019 